\title{
СПЕЦИФІКА СПОЖИВАННЯ КІНОПРОДУКТУ ЯК КАТАЛІЗАТОР НОВАЦІЙНИХ МИСТЕЦЬКИХ ТЕХНОЛОГІЙ
}

У статті досліджується питання кіноспоживання, його поступове перетворення з публічного в приватне у зв'язку зі стрімким розвитком технологій. Ставиться питання про зміну специифіки кіноспоживання як причину впровадження нових технологій звуку $і$ зображення в кінотеатрах, а також розглядається вилив изих нововведень на кіномову.

Ключові слова: кіноспоживання, системи багатоканального звуку, просторовий звук, Dolby Stereo, Doldy Atmos, DTS, SDDS, широкоформатні кінематографічні системи, IMAX Digital, кіномова.

В статье исследуется вопрос потребления кино, его постепенное превращение из публичного в частное в связи со стремительным развитием технологий. Ставится вопрос о смене спеиифики потребления кино как о причине внедрения новых технологий звука и изображения в кинотеатрах, $a$ также рассматривается влияние данных нововведений на киноязык.

Ключевые слова: потребление кино, системы многоканального звука, пространственный звук, Dolby Stereo, Doldy Atmos, DTS, SDDS, широкоформатный кинематографические системы, IMAX Digital, киноязык.

The article describes a research of cinema consumption and its gradual transformation from public to private. It also lightens a question of change consumption specifisity as a reason of implementing new sound and image technologies in Cinema. In addition, it indicates influence of mentioned innovations on cinematic language.

Key words: cinema consumption, multichannel sound systems, surround sound, Dolby Stereo, Doldy Atmos, DTS, SDDS, widescreen cinema systems, broadcast cinematic language.

Ми живемо в постіндустріальному суспільстві, яке характеризується значними змінами соціокультурного контексту. Розвиток технологій і глобалізація не могли не вплинути на кіноспоживання. Якщо раніше воно було централізованим, то з часом спостерігається тенденція до індивідуалізації кінопереглядів, чому значною мірою посприяла поява нових носіїв, а також перенесення систем зображення та звуку в домашні умови. Кіноспоживання 3 публічного стає дедалі більш приватним, домашнім.

Сучасні українські дослідники Ю. Сорока, Н. Костенко, Р. Шульга, а також російські М. Жабський, Ю. Фохт-Бабушкін [6] та К. Тарасов багато уваги приділили питанню кіноспоживання, його впливу на розвиток суспільства, політику та культуру. Також російський кінознавець М. Хрєнов у своїй дисертації «Культурологічний аспект вивчення публіки як комунікативної спільноти» 1992 року розглядав еволюцію сприйняття кіно - від простого видовища, яке має на меті компенсувати дефіцит емоцій, до його формування в соціальний інститут [5]. Канадський філософ Маршалл Маклюен вважав, що глядач сприймає кіно радше через співпереживання і активне залучення, ніж через засвоєння інформації, і подекуди втрачає критичне мислення, тож пріоритетною $\epsilon$ емоційна складова [7].

Сучасний культурний плюралізм зумовив перетворення кіноаудиторії з пасивного споживача на творця власного кінодосвіду [2]. Розмаїття жанрів та носіїв сприяло тому, що кінотеатр уже давно не є єдиною можливістю для споглядання фільмів. Бурхливий розвиток телебачення в 1950-х роках, а згодом поширення фільмів на носіях та в мережі Інтернет здешевили для спожи- 
вача перегляд фільмів і зробили його можливим в домашніх умовах.

Вибір фільму для перегляду більше не обмежується політикою місцевого кінотеатру, він обумовлений винятково побажаннями глядача. В свою чергу, досить часто глядачеві вже недостатньо просто цікавого сюжету, аби вирішити відвідати кінотеатр. Дуже часто він іде в кінотеатр заради того, чого не може отримати при домашньому перегляді, - надвеликого екрана, тривимірного зображення та просторового звуку. Отримати яскраві зорові, слухові відчуття та подекуди відчуття втрати рівноваги, яке досягається за допомогою подразнення звуками вестибулярного апарата внутрішнього вуха. I саме прагнення знову повернути культурну практику споглядання кіно 3 дому в кінотеатр спричинило активний розвиток новітніх технологій звуку та зображення.

Ще в 1940 році в «Фантазії» Волта Діснея вже було цілих три незалежних канали звуку. Система Fantasound від звичного монофонічного звуку одразу зробила ривок до 3-канального. Діснея надихнув твір Ніколая Римського-Корсакова «Політ джмеля». Він хотів, щоб звук у його фільмі переміщувався, «літав» в усіх частинах кінотеатру. Ефект просторового звуку був досягнутий за рахунок суми та різниці фази.

Демонстрація фільму вимагала від 30-ти до 80-ти гучномовців, встановлених по периметру залу та за екраном. Також стрічка вирізнялась більш насиченим звуком, що досягалося за рахунок ширшого динамічного діапазону. На жаль, такі масштабні покази фільму були невигідними для кінотеатрів. До того ж, Друга світова війна на деякий час відсунула роботу над об'ємним звуком на другий план.

Справжнім проривом стала демонстрація стрічки «Це - “Сінерама”!» (реж. Меріан К. Купер) у Бродвейському театрі Нью-Йорка у вересні 1952 року. Розробники представили глядачам революційну панорамну кінематографічну систему 3 горизонтальним кутом огляду 146 градусів та одразу 7-ма каналами звуку [1]. Вже цілих п'ять каналів слугували панорамуванню звуку, інші два були каналами «оточення».

Слід відзначити, що початок фільму - чорно-білий, зі стандартним співвідношенням 4:3. Журналіст Лоуелл Томас читає лекцію про еволюцію рухомого зображення від первісних печерних малюнків до приходу кольору і звуку в кіно. Закінчує лекцію він словами «Це - “Сінерама”!», і екран розширюється до стандарту Сінерами $2,65: 1$, а зображення стає кольоровим.
Надалі кількість каналів звуку лише збільшувалась, згодом 3'явився також окремий канал низькочастотних ефектів для більшого впливу на глядачів. Компанії Dolby Laboratories Inc., DTS та Sony влаштували справжні «перегони озброєнь», пропонуючи споживачеві дедалі більше занурення в атмосферу за допомогою об'ємного звуку. Стрічки «Зоряні війни: Нова надія» (1977 рік, реж. Джордж Лукас) 3 4-канальним звуком від Dolby Stereo, «Бетмен повертається» (1992 рік, реж. Тім Бертон) в системі Dolby Stereo Digital (п'ять повнодіапазонних каналів і один канал низькочастотних ефектів, іiі також називають 5.1), «Парк Юрського періоду» (1993 рік, реж. Стівен Спілберг) в системі DTS з 5.1-канальним звуком, «Останній кіногерой» (1993 рік, реж. Джон Мактірнан) у системі SDDS від Sony та подальші фільми 3 просторовим звуком яскраво демонструють стрімкий розвиток багатоканальних систем та прагнення розробників створити ще більш насичений і вражаючий звуковий простір для глядача [3].

Але 3 часом багатоканальний звук став можливим і при домашньому перегляді. Ефектне оточення звуком і переміщення джерел звуку для більшої реалістичності зображуваного вже не були прерогативою лише кінотеатрів. Тому згодом перед розробниками постало завдання створити принципово нову звукову систему, аби вразити вже досвідченого глядача.

Компанія Dolby Laboratories Inc., яка починала зі створення систем пониження шуму, згодом взялася за розробку аналогового, а надалі й цифрового багатоканального звуку. В 2012 році вона презентувала технологію об'ємного звуку Dolby Atmos, вперше застосовану в анімаційному фільмі «Хоробра серцем» (реж. Марк Ендрюс, Бренда Чемпмен, Стів Пурсел). Новітня система демонструє принципово новий підхід до багатоканального звуку. Усі складові звукової партитури розподіляються на статичні (наприклад, музика) і динамічні (рухомі джерела звуку). Звукові надається така сама траєкторія, як і видимим об'єктам. Така технологія багатоканального звуку була використана в фільмах «Гравітація», «Ла Ла Ленд», «Шалений Макс: Дорога гніву», «Легенда Г'ю Гласса» «3 міркувань совісті» та ін.

Слід зазначити, що вже в 2014 році компанія Dolby Laboratories Inc. анонсувала прихід Dolby Atmos в домашні кінотеатри. Першим телесеріалом, що використав таку технологію, став серіал виробництва каналу НВО «Гра престолів». 32016 року серії видаються на дисках Blu-ray з застосу- 
ванням технологіï Dolby Atmos. Цей факт дає певні підстави висловити припущення, що незабаром розробники анонсують новий звуковий «атракціон» для кінотеатрів.

Не стояло на місці і зображення. Спроби перейти від двовимірного зображення до тривимірного мали місце невдовзі після запуску «сінематографа» братів Люм'єр - наприкінці 1890-х років британський винахідник Вільям Фрізе-Грін подав патентну заявку на метод виробництва стереоскопічного фільму з використанням двох плівок. Також у 1900 році Фредерік Юджин Ів запатентував устаткування для стереозйомки [4].

Перший показ стереоскопічного фільму відбувся 27 вересня 1922 року в Лос-Анджелесі. Це була стрічка «Сила любові» режисерів Ната Деверіча та Гаррі Фейролла. Винайдення в 1929 році поляризуючої плівки стало новим витком у розвитку стереозображення.

Треба зауважити, що «золотий вік» стереокінематографа збігається з розвитком телебачення, зокрема, з запуском кольорового телебачення. Глядачеві потрібен був яскравий атракціон, а кіностудіям - надійна «зброя» у протистоянні 3 телебаченням. I касовий успіх стереоскопічних фільмів «Дім воскових фігур» (реж. Андре де Тот) кіностудіï Warner Brothers та «Людина в темряві» (реж. Лею Ландерс) виробництва Columbia Pictures продемонстрував, що стереокінематограф насправді став дієвим інструментом для приваблювання глядачів у кінотеатри.

Черговий спалах інтересу до стереокіно 3'явився 3 винайденням одноплівкового формату. А в 1980-х роках величезну популярність завоювала широкоформатна система стереокінематографа IMAX.

IMAX (від «Image Maximum»- «максимальне зображення») від корпорації «Мультискрін» вимагав лише однієї камери та одного проектора. Площа кадру i, відповідно, площа екрана втричі більші, ніж у решті широкоформатних систем. Перший кінотеатр IMAX «Кіносфера» був відкритий у Торонто в 1971 році. В 2008 році був запущений цифровий стандарт IMAX Digital. А в 2014 році в Торонто відкрився перший кінотеатр 3 новітньою системою цифрової проекції за допомогою двох лазерних проекторів з розширенням 4К.

Технічні інновації викликали зміни і в кіномові. Особливої популярності набули фільми «екшн» 3 насиченою драматургією, динамічним монтажем та нерідко з вражаючою комп'ютерною графікою. Кінематографічний «атракціон» дає змогу отримати гострі враження, подібні до катання на «американських гірках». Відчути невагомість космосу, політ, вибухи тощо. Щоб увага глядача не розсіювалась, його постійно тримають у напрузі, регулярно додаючи певні подразники. Це може бути різка зміна кадру, яскравий візуальний ефект, несподіваний голосний звук або неочікувана звукова фактура.

Поява багатоканального звуку також дала можливість скоротити кількість загальних планів. Просторовий звук дає вичерпне уявлення про розташування об'єктів у кадрі, тому немає потреби постійно нагадувати про це глядачеві повторенням загального плану. Таким чином, з'явилася можливість «наблизитись» до екранних подій, сконцентрувавшись на середніх та крупних планах. Акценти на емоціях героїв, які найбільше проявляються саме в крупних планах, та деталізація дають змогу глядачеві не спостерігати збоку, а самому зануритись у зображувані події та відчути себе їх учасником.

Сьогодні кінематограф переживає етап трансформації. Важко зробити однозначний висновок, чи революційні візуальні та звукові ефекти посядуть місце безпосередньо кіномови, чи стануть ще одним iї інструментом. Зважаючи на те, що подібні суперечки супроводжували і прихід звуку в кіно, можна зробити оптимістичне припущення, що технологічний бум стане черговим витком у розвитку кінематографа.

Зміна специфіки споживання кіно перетворила його з яскравої події в житті на елемент буденного життя. Тому творці фільмів часто прагнуть, аби кіно знову захоплювало і вражало, застосовуючи для цього і видозмінену кіномову, і новітні технічні надбання.

\section{Джерела та література:}

1. Tomlinson, Holman (2007). Surround sound: up and running. - Focal Press. $-240 \mathrm{p}$.

2. Типологія кіноспоживання в сучасному соціокультурному просторі України [Текст] : автореф. дис... канд. соціол. наук : 22.00.04 / Виставкіна Дар'я Олегівна ; Харківський національний ун-т ім. В. Н. Каразіна. - Х., 2009. - 21 с.

3. Чекалин Д. Г. О многоканальном звуковоспроизведении // «Мир техники кино». - 2008. - № 8. - С. 14-19.

4. Проворнов С. М. Глава VIII. Стереоскопическое кино // Кинопроекционная техника. - изд. 2-е. - М. : «Искусство», 2004. - Т. 1. -458 с.

5. Хренов Н. А. Избранные работы по культурологии. - М. : Согласие, 2014.

6. Фохт-Бабушкин Ю. У. Художественная культура: Проблемы изучения и управления / Ю. У. Фохт-Бабушкин. М. : Наука, 1986. -343 с.

7. Маклюэн М. Понимание медиа: внешние расширения человека / М. Маклюэн ; пер. с англ. В. Николаева. - М. : Жуковский, «КАНОН-пресс-Ц», «Кучково поле», 2003. $464 \mathrm{c}$. 


\section{References}

1. Tomlinson, Holman (2007). Surround sound: up and running. - Focal Press, 240 [in England].

2. Typolohiia kinospozhyvannia v suchasnomu sotsiokulturnomu prostori Ukrainy [Tekst] : avtoref. dys... kand. sotsiol. nauk : 22.00.04 / Vystavkina Daria Olehivna ; Kharkivskyi natsionalnyi un-t im. V. N. Karazina. - Kharkiv, 2009, 21 [in Ukrasnian].

3. Chekalin, D. G. (2008). O mnogokanalnom zvukovosproizvedenii // «Mir tehniki kino». - № 8. [in Russian].
4. Provornov, S. M. (2004). Glava VIII. Stereoskopicheskoe kino // Kinoproektsionnaya tehnika. - izd. 2-e. - T. 1. Moscow : Iskusstvo, 458 [in Russian].

5. Khrenov, N. A. (2014). Izbrannyie rabotyi po kulturologii. Moscow : Soglasie [in Russian].

6. Foht-Babushkin, Yu. U. (1986). Hudozhestvennaya kultura: Problemyi izucheniya i upravleniya. - Moscow : Nauka, 343 [in Russian].

7. Maklyuen, M. (2003). Ponimanie media: vneshnie rasshireniya cheloveka ; per. s angl. V. Nikolaeva. - Moscow : Zhukovskyi, «KANON-press-Ts», «Kuchkovo pole», 464 [in Russian]. 